\title{
Positive Motivation and Hope during Addictive Diseases Treatment
}

Prim. MUDr. Karel Nešpor, CSc.

\section{Introduction}

Hope improves the results of treatments for many health problems (Wiles et al., 2008) including mental health problems (Werner, 2012, Stickley and Wright, 2011). It eases symptoms of depression, makes handling pain easier (Peerdeman et al., 2016) and improves quality of life. In case of addictive diseases, hope enables the patients to shift from the stage of hesitating to the stage of making a decision that leads to a positive change (more about stages of motivation in Czech language e.g. Nešpor, 2011). Treatment of addictive disease should be long-term and systematic, which means it requires great cooperation from the patient. Hope allows for better cooperation and motivates patients to undergo long-term aftercare (Corrigan, 2014).

\section{Possible ways to strengthen hope during addictive disease treatment}

-It is crucial to establish meetings with the long-term abstainers. For this purpose, there are self-help organizations such as Alcoholics Anonymous, or aftercare groups and sociotherapeutic clubs. Strengthening hope is not the only reason why these activities are useful. They also give patients a chance for social learning and gaining support from people in similar situation (so called peer support, Simpson et al., 2014). Participation in this type of self-help organization also makes them feel useful, strengthens their confidence and has a positive effect on their network of social relationships (Kelly et al., 2012).

- The therapist may use the experience of successfully treated addicts and tell the stories of anonymous abstainers, who were in similar situation as the patients and managed to cope with it.

- Hope is closely related to setting and achieving goals. Both extremes are unhealthy - whether its resignation or setting unrealistic goals. Large goals need to be separated into individual steps which will be gradually implemented. At the same time, it is important not to forget maintaining sobriety, good health and adequate rest. This approach helps the addicted patients to ease symptoms of depression and apparently facilitates abstinence (Raisian et al., 2010, Karimyar and Mosallanejad, 2014). When setting and achieving goals, it also helps to be flexible with respect to changes in patient's possibilities and situation.

- In order to strengthen trust and hope, patients past achievements, abilities, intelligence etc. can be emphasized. It can also be useful to focus on the good options that the patient has.

- It has proven to be effective to ask one of the patients to do a presentation about an appropriate topic. For example, a cook can talk about how they prepared a cheap and healthy dinner. That is in accordance with the principles of the therapeutic community, which include active participation in own treatment as well as the treatment of others. 
-Laughter and humor belong to the most pleasant ways to relax, calm down and strengthen hope. Of course the therapist must be delicate when using humor.

- Hope is also affected by therapist's non-verbal communication. For example a gloomy expression may be perceived by the patient as a negative prognosis, on the other hand, a smile can be perceived as a sign of confidence, which encourages hope.

- Motivation to stay sober and have hope can be increased even by small joys and healthy and pleasant forms of active rest. That includes relaxation techniques such as yoga, qigong, hiking and other safe forms of physical activity.

-An important factor, which raises hope, is social support from people around (Du et al., 2015). Having an addictive disease often has a negative impact on network of social relationships. Especially socially isolated patients are often advised to intensively cooperate with a self-help organization such as Alcoholics Anonymous or with a sociotherapeutic club.

- Hope and self-confidence can be strengthened even by mastering relevant skills, including social skills.

- Certain patients find their source of hope in spirituality, which is sometimes called "transcendent hope“.

\section{Conclusion}

Long-term cooperation, which is required for treatment of addictive diseases, is easier with hope. This article mentions some specific ways to strengthen hope.

\section{Literature}

CORRIGAN PW. Can there be false hope in recovery? Br J Psychiatry. 2014; 205(6):423-4.

DU H, KING RB, CHU SK. Hope, social support, and depression among Hong Kong youth: personal and relational self-esteem as mediators. Psychol Health Med. 2015 Dec 30:1-6. [Epub ahead of print]

KARIMYAR JM, MOSALLANEJAD L. The impact of reality therapy on metacognition, stress and hope in addicts. Glob J Health Sci. 2014; 6(6):281-7.

KELLY JF, HOEPPNER B, STOUT RL, Pagano M. Determining the relative importance of the mechanisms of behavior change within Alcoholics Anonymous: a multiple mediator analysis. Addiction. 2012; 107(2):28999.

NEŠPOR K. Návykové chování a závislost, 4. aktualizované vydání. Praha: Portál 2011; 176.

PEERDEMAN KJ, VAN LAARHOVEN AI, PETERS ML, EVERS AW. An Integrative Review of the Influence of Expectancies on Pain. Front Psychol. 2016; 7:1270. 
RAISIAN A, GOLZARI M, BORJALI A. Effectiveness of Hope Therapy On reduction of depression and relapse prevention in women clients with drug-dependent. Q Addict of Addiction Stud and Subt Abuse. 2010; 5(17):32-41.

SIMPSON A, FLOOD C, ROWE J, QUIGLEY J, HENRY S, HALL C, EVANS R, SHERMAN P, BOWERS L. Results of a pilot randomised controlled trial to measure the clinical and cost effectiveness of peer support in increasing hope and quality of life in mental health patients discharged from hospital in the UK. BMC Psychiatry. 2014; $14: 30$.

STICKLEY T, WRIGHT N. The British research evidence for recovery, papers published between 2006 and 2009 (inclusive). Part One: a review of the peer-reviewed literature using a systematic approach. J Psychiatr Ment Health Nurs. 2011; 18(3):247-56.

WERNER S. Subjective well-being, hope, and needs of individuals with serious mental illness. Psychiatry Res. 2012; 196(2-3):214-9.

WILES R, COTT C. GIBSON BE. Hope, expectations and recovery from illness: A narrative synthesis of qualitative research. Journal of Advanced Nursing 2008; 64 (6): 564-573.

Prim. MUDr. Karel Nešpor, CSc.

www.drnespor.eu, www.youtube.com/drnespor

mužské oddělení léčby závislostí

Psychiatrická nemocnice Bohnice

18102 Praha 8 